\title{
HISTIDINE DECARBOXYLASE IN HYALINE MEMBRANE DISEASE
}

\author{
BY \\ ROSS G. MITCHELL* \\ From the Department of Child Health, University of St. Andrews
}

(RECEIVED FOR PUBL CATION AUGUST 12, 1963)

During the latter part of pregnancy, the foetal rat produces large quantities of histamine which may be concerned with the growth of the foetus (Kahlson and Rosengren, 1959). Kahlson (1960) reported increased formation of histamine by the human foetus as well: recently Davis (1961) suggested that the antagonism of such excess histamine might account for the beneficial effect of an antihistamine drug (chlorpheniramine) on the respiratory distress of premature infants. It is not unlikely that endogenously-formed histamine participates in the genesis of hyaline membrane, since histamine is believed to regulate the microcirculation (Schayer, 1962), and circulatory changes following hypoxia may play an important role in hyaline membrane formation (Cook, 1962; Wade-Evans, 1962).

The histamine formed by the foetal rat is produced in the liver by a specific L-histidine decarboxylase (Kahlson, Rosengren and White, 1959; Telford and West, 1961; Burkhalter, 1962). The present work was undertaken to determine whether abnormally increased histidine decarboxylase activity could be detected in the tissues of infants dying of hyaline membrane disease.

\section{Methods and Procedure}

Histidine decarboxylase activity was measured by a method similar to that of Mackay and Shepherd (1960); full details have been recorded elsewhere (Mitchell, 1963). The tissue was ground with sand and saline, centrifuged, and the supernatant fluid incubated at $37^{\circ} \mathrm{C}$. for three hours with L-histidine in the presence of the co-enzyme pyridoxal-5'-phosphate and of aminoguanidine. The mixture was buffered to the required $p \mathrm{H}$, either 9 or 6.5 in all the experiments reported here. At $p \mathrm{H} 9$, the activity was potentiated by the addition of one drop of benzene; benzene was not added when the incubation was carried out at $p \mathrm{H} 6 \cdot 5$. The reaction was stopped by acidifying to $p \mathrm{H} 5.8$ and boiling to coagulate the protein. The mixture was then centrifuged and the

* Present address: Department of Child Health, University of Aberdeen. supernatant fluid brought to $p \mathrm{H} 7 \cdot 0$ before assay, which was carried out immediately on a strip of guinea-pig ileum suspended in atropinized 'tyrode' solution. Histidine decarboxylase activity was expressed as micrograms of histamine (free base) formed by $1 \mathrm{~g}$. of tissue in three hours' incubation. This value was obtained by subtracting the value for preformed histamine (if any) from the total quantity of histamine present after incubation with L-histidine. In each experiment, a mixture containing the tissue without $\mathrm{L}$-histidine and another containing L-histidine without tissue were incubated simultaneously in order to measure any preformed histamine in the tissue and to detect any non-enzymic decarboxylation of histidine. The incubations were not carried out under sterile conditions, but bacteriological culture of the mixture after incubation showed that there was no growth of organisms that might have accounted for the histamine formed.

In one series of experiments, the supernatant fluid from the tissue extract was dialysed to remove histamine before incubation. Dialysis was carried out in 5 litres of $0.9 \%$ saline at $4^{\circ} \mathrm{C}$. for 18 hours. In each experiment, an aliquot of the undialysed supernatant fluid was kept under the same conditions for comparison.

Body tissues were obtained as quickly as possible after death, in all cases within 24 hours, and in 17 of the 22 cases studied within 12 hours. Tissues were immediately frozen at $-20^{\circ} \mathrm{C}$. until extracted. Previous work has shown that the enzyme is stable under these conditions (Mitchell, 1963).

Histidine decarboxylase was measured in the tissues of infants with hyaline membrane disease, proved in each case by histological examination, and of liveborn infants dying more than one hour after birth from conditions other than hyaline membrane disease. None of the latter group showed clinical evidence of respiratory distress.

Histidine decarboxylase was also measured in the femoral bone marrow of six other newborn infants.

\section{Results}

The greatest histidine decarboxylating activity was found in kidney when the incubation was carried out at $p \mathrm{H} 9 \cdot 0$. The mean value for this activity in the kidneys of 13 infants with hyaline 
TABLE 1

HISTIDINE DECARBOXYLASE IN KIDNEY, LIVER AND LUNG OF 13 INFANTS WITH HYALINE MEMBRANE DISEASE

(Enzyme activity is expressed as $\mu \mathrm{g}$. histamine per $\mathrm{g}$. of tissue formed at $p \mathrm{H} \mathrm{9)}$

\begin{tabular}{|c|c|c|c|c|c|c|c|c|c|c|}
\hline \multirow{2}{*}{$\begin{array}{c}\text { Case } \\
\text { No. }\end{array}$} & \multirow[b]{2}{*}{ Sex } & \multirow[b]{2}{*}{$\begin{array}{c}\text { Body } \\
\text { Weight } \\
\text { (g.) }\end{array}$} & \multirow{2}{*}{$\begin{array}{c}\text { Gesta- } \\
\text { tional } \\
\text { Age } \\
\text { (wks.) }\end{array}$} & \multirow[b]{2}{*}{$\begin{array}{l}\text { Age at } \\
\text { Death } \\
\text { (hrs.) }\end{array}$} & \multicolumn{2}{|c|}{ Kidney } & \multicolumn{2}{|c|}{ Liver } & \multicolumn{2}{|c|}{ Lung } \\
\hline & & & & & $\begin{array}{c}\text { Preformed } \\
\text { Histamine } \\
(\mu \mathrm{g} . / \mathrm{g} .)\end{array}$ & $\begin{array}{c}\text { Histidine } \\
\text { Decarboxylase } \\
(\mu \mathrm{g} . / \mathrm{g} .)\end{array}$ & $\begin{array}{l}\text { Preformed } \\
\text { Histamine } \\
(\mu \mathrm{g} . / \mathrm{g} .)\end{array}$ & $\begin{array}{c}\text { Histidine } \\
\text { Decarboxylase } \\
(\mu \mathrm{g} / \mathrm{g} .)\end{array}$ & $\begin{array}{c}\text { Preformed } \\
\text { Histamine } \\
(\mu \mathrm{g} . / \mathrm{g} .)\end{array}$ & $\begin{array}{c}\text { Histidine } \\
\text { Decarboxylase } \\
(\mu \mathrm{g} . / \mathrm{g} .)\end{array}$ \\
\hline $\begin{array}{r}1 \\
2 \\
3 \\
4 \\
5 \\
6 \\
7 \\
8 \\
9 \\
10 \\
11 \\
12 \\
13\end{array}$ & $\begin{array}{l}\mathbf{M} \\
\mathbf{M} \\
\mathbf{M} \\
\mathbf{F} \\
\mathbf{F} \\
\mathbf{F} \\
\mathbf{F} \\
\mathbf{M} \\
\mathbf{M} \\
\mathbf{M} \\
\mathbf{M} \\
\mathbf{F} \\
\mathbf{F}\end{array}$ & $\begin{array}{r}795 \\
795 \\
475 \\
750 \\
1,000 \\
1,310 \\
1,030 \\
1,130 \\
2,010 \\
1,600 \\
1,860 \\
1,890 \\
2,410\end{array}$ & $\begin{array}{l}22 \\
22 \\
26 \\
27 \\
29 \\
29 \\
30 \\
33 \\
34 \\
34 \\
34 \\
34 \\
36\end{array}$ & $\begin{array}{c}2 \\
1 \frac{1}{2} \\
6 \\
13 \\
7 \\
17 \\
15 \\
31 \\
22 \\
17 \\
21 \\
19 \\
36\end{array}$ & $\begin{array}{l}0 \cdot 08 \\
0 \\
0 \\
0 \cdot 04 \\
0 \\
0 \\
0 \\
0 \\
0 \\
0 \\
0 \\
0 \cdot 07 \\
0 \cdot 07\end{array}$ & $\begin{array}{l}1.92 \\
0.71 \\
1.33 \\
2.96 \\
1.33 \\
4.00 \\
0.60 \\
0.96 \\
3.00 \\
2.85 \\
2.14 \\
3.53 \\
0.65\end{array}$ & $\begin{array}{l}0 \cdot 08 \\
0 \\
0 \\
0 \\
0 \\
0 \\
0 \\
0 \\
0 \\
0 \cdot 05 \\
0 \\
0 \\
0\end{array}$ & $\begin{array}{l}0.92 \\
0.40 \\
0.45 \\
1.20 \\
0.48 \\
1.50 \\
0.30 \\
0.24 \\
1.00 \\
0.79 \\
1.09 \\
2.10 \\
0.12\end{array}$ & $\begin{array}{l}0 \cdot 05 \\
0 \\
\overrightarrow{0 \cdot 10} \\
0 \\
- \\
0 \\
0 \\
0 \\
0 \cdot 04 \\
0 \\
0 \\
0\end{array}$ & $\begin{array}{l}0.55 \\
0 \\
0.04 \\
0 \\
0 \\
0 \\
0 \\
0.06 \\
0.06 \\
0.09 \\
0.96 \\
0.05\end{array}$ \\
\hline \multicolumn{2}{|c|}{ Mean } & 1,312 & 30 & 16 & 0.02 & $2 \cdot 00$ & 0.01 & 0.81 & 0.02 & $0 \cdot 16$ \\
\hline
\end{tabular}

Dashes $(-)$ indicate that tissue was not examined.

TABLE 2

HISTIDINE DECARBOXYLASE ( $p \mathrm{H} 9 \cdot 0)$ IN KIDNEY, LIVER AND LUNG OF EIGHT INFANTS DYING IN THE FIRST WEEK OF LIFE FROM CAUSES ÓTHER THAN HYALINE MEMBRANE DISEASE

\begin{tabular}{|c|c|c|c|c|c|c|c|c|c|c|}
\hline \multirow{2}{*}{$\begin{array}{l}\text { Case } \\
\text { No. }\end{array}$} & \multirow[b]{2}{*}{ Sex } & \multirow[b]{2}{*}{$\begin{array}{c}\text { Body } \\
\text { Weight } \\
\text { (g.) }\end{array}$} & \multirow{2}{*}{$\begin{array}{c}\text { Gesta- } \\
\text { tional } \\
\text { Age } \\
\text { (wks.) }\end{array}$} & \multirow{2}{*}{$\begin{array}{l}\text { Age at } \\
\text { Death } \\
\text { (hrs.) }\end{array}$} & \multicolumn{2}{|c|}{ Kidney } & \multicolumn{2}{|c|}{ Liver } & \multicolumn{2}{|c|}{ Lung } \\
\hline & & & & & $\begin{array}{c}\text { Preformed } \\
\text { Histamine } \\
(\mu \mathrm{g} . / \mathrm{g} .)\end{array}$ & $\begin{array}{c}\text { Histidine } \\
\text { Decarboxylase } \\
(\mu \mathrm{g} . / \mathrm{g} .)\end{array}$ & $\begin{array}{c}\text { Preformed } \\
\text { Histamine } \\
(\mu \mathrm{g} . / \mathrm{g} .)\end{array}$ & $\begin{array}{c}\text { Histidine } \\
\text { Decarboxylase } \\
(\mu \mathrm{g} . / \mathrm{g} .)\end{array}$ & $\begin{array}{c}\text { Preformed } \\
\text { Histamine } \\
(\mu \mathrm{g} . / \mathrm{g} .)\end{array}$ & $\begin{array}{c}\text { Histidine } \\
\text { Decarboxylase } \\
(\mu \mathrm{g} . / \mathrm{g} .)\end{array}$ \\
\hline $\begin{array}{l}14 \\
15 \\
16 \\
17 \\
18 \\
19 \\
20 \\
21\end{array}$ & $\begin{array}{l}\mathbf{F} \\
\mathbf{M} \\
\mathbf{F} \\
\mathbf{M} \\
\mathbf{M} \\
\mathbf{M} \\
\mathbf{M} \\
\mathbf{M}\end{array}$ & $\begin{array}{r}750 \\
1,420 \\
1,790 \\
2,030 \\
2,450 \\
2,315 \\
2,610 \\
3,835\end{array}$ & $\begin{array}{l}26 \\
32 \\
32 \\
35 \\
36 \\
38 \\
40 \\
40\end{array}$ & $\begin{array}{r}37 \\
61 \\
5 \\
79 \\
105 \\
1 \\
1 \\
36\end{array}$ & $\begin{array}{l}0 \\
0 \\
0 \\
0 \\
0 \\
0 \\
0 \\
0\end{array}$ & $\begin{array}{l}2 \cdot 00 \\
1 \cdot 20 \\
3 \cdot 00 \\
6 \cdot 32 \\
2 \cdot 00 \\
1 \cdot 67 \\
3 \cdot 43 \\
2 \cdot 40\end{array}$ & $\begin{array}{l}0 \\
0 \\
0 \\
0 \\
0 \\
0 \\
0 \cdot 24 \\
0\end{array}$ & $\begin{array}{l}0 \cdot 80 \\
0 \cdot 10 \\
0 \cdot 48 \\
1 \cdot 09 \\
2 \cdot 40 \\
1 \cdot 20 \\
0 \cdot 56 \\
1 \cdot 09\end{array}$ & $\begin{array}{l}0 \\
0 \\
0 \\
0 \\
0 \\
0 \\
-\end{array}$ & $\begin{array}{l}0 \\
0 \cdot 21 \\
0 \\
0 \\
0 \cdot 18 \\
0 \cdot 23 \\
=\end{array}$ \\
\hline \multicolumn{2}{|c|}{ Mean } & 2,150 & 35 & 40 & 0 & $2 \cdot 75$ & 0.03 & 0.97 & 0 & $0 \cdot 10$ \\
\hline
\end{tabular}

Note. Cases 14-17 died from anoxia, Cases 18-20 from congenital malformation, Case 21 from intracranial haemorrhage.

Dashes (-) indicate that tissue was not examined.

membrane disease was $2 \cdot 00 \mu \mathrm{g} . / \mathrm{g}$. (Table 1$)$, which does not differ significantly $(p>0 \cdot 2)$ from the mean value of $2 \cdot 75 \mu \mathrm{g}$. $/ \mathrm{g}$. for eight control infants (Table 2) or from the mean value of $1.91 \mu \mathrm{g}$./g. reported previously for premature infants (Mitchell, 1963).

Smaller quantities of histidine decarboxylase were present in liver and lung at $p \mathrm{H} 9 \cdot 0$ and there were no significant differences between the mean values for the hyaline membrane group and those for the control group (Tables 1 and 2). Only traces of histidine decarboxylase were found at $p \mathrm{H} 6.5$ in the kidneys, livers and lungs of the three hyaline membrane infants and four control infants tested. Neither at $p \mathrm{H} 9.0$ nor at $p \mathrm{H} 6.5$ were there more than very small quantities of preformed histamine in any of these tissues, though it should be noted that the method would not detect histamine bound in the tissues, which could only be assayed after prolonged boiling in strong acid (Barsoum and Gaddum, 1935).

Histidine decarboxylase was measured at $p \mathbf{H ~ 9 \cdot 0}$ and 6.5 in stomach and spleen of two hyaline membrane infants and three control infants. Only

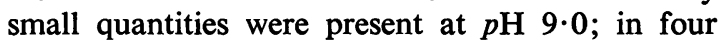
of the five cases, the amount of preformed histamine in stomach was greater than the amount formed during incubation with L-histidine (Table 3 ). There was little or no enzyme activity at $p \mathrm{H} 6 \cdot 5$, the mean values for the five infants being $0.16 \mu \mathrm{g} . / \mathrm{g}$. for both stomach and spleen.

Histidine decarboxylase was measured in abdominal skin of three hyaline membrane infants and six control infants. Relatively large amounts of preformed histamine were found, the mean value for the three hyaline membrane cases being lower than that for the controls $(0.71$ and $1.79 \mu \mathrm{g}$. $/ \mathrm{g}$. 
TABLE 3

HISTIDINE DECARBOXYLASE ( $p$ H 9 ) IN STOMACH, SPLEEN AND SKIN OF FIVE NEWBORN INFANTS

\begin{tabular}{|c|c|c|c|c|c|c|}
\hline \multirow[b]{2}{*}{ Case No. } & \multicolumn{2}{|c|}{ Stomach } & \multicolumn{2}{|c|}{ Spleen } & \multicolumn{2}{|c|}{ Skin } \\
\hline & $\begin{array}{c}\text { Preformed } \\
\text { Histamine } \\
(\mu \mathrm{g} . / \mathrm{g} .)\end{array}$ & $\begin{array}{c}\text { Histidine } \\
\text { Decarboxylase } \\
(\mu \mathrm{g} . / \mathrm{g} .)\end{array}$ & $\begin{array}{l}\text { Preformed } \\
\text { Histamine } \\
(\mu \mathrm{g} . / \mathrm{g} .)\end{array}$ & $\begin{array}{c}\text { Histidine } \\
\text { Decarboxylase } \\
(\mu \mathrm{g} . / \mathrm{g} .)\end{array}$ & $\begin{array}{c}\text { Preformed } \\
\text { Histamine } \\
(\mu \mathrm{g} / \mathrm{g} .)\end{array}$ & $\begin{array}{c}\text { Histidine } \\
\text { Decarboxylase } \\
(\mu \mathrm{g} . / \mathrm{g} .)\end{array}$ \\
\hline $\begin{array}{r}3 \\
6 \\
17 \\
20 \\
21\end{array}$ & $\begin{array}{l}0.15 \\
0.42 \\
0.72 \\
0.48 \\
2.40\end{array}$ & $\begin{array}{l}0.45 \\
0.24 \\
0.48 \\
0.37 \\
1.20\end{array}$ & $\begin{array}{l}0 \\
0 \cdot 15 \\
0 \\
0 \\
0 \cdot 08\end{array}$ & $\begin{array}{l}0.82 \\
0 \cdot 11 \\
0 \\
0 \cdot 15 \\
0.24\end{array}$ & $\begin{array}{l}0 \cdot 45 \\
0 \cdot 60 \\
2 \cdot 70 \\
0 \\
4 \cdot 50\end{array}$ & $\begin{array}{l}0.63 \\
1.90 \\
0.90 \\
0.75 \\
1.93\end{array}$ \\
\hline Mean & 0.83 & 0.55 & 0.05 & $0 \cdot 26$ & $1 \cdot 65$ & $1 \cdot 22$ \\
\hline
\end{tabular}

TABLE 4

PREFORMED HISTAMINE AND HISTIDINE DECARBOXYLASE BEFORE AND AFTER DIALYSIS OF SKIN AND KIDNEY OF FOUR NEWBORN INFANTS

\begin{tabular}{|c|c|c|c|c|c|c|c|c|c|c|}
\hline \multirow{3}{*}{ Tissue } & & \multirow{3}{*}{ Case No. } & \multicolumn{4}{|c|}{ Preformed Histamine ( $\mu \mathrm{g} . / \mathrm{g})}$. & \multicolumn{4}{|c|}{ Histidine Decarboxylase ( $\mu \mathrm{g} . / \mathrm{g})}$. \\
\hline & & & \multicolumn{2}{|c|}{ Undialysed } & \multicolumn{2}{|c|}{ Dialysed } & \multicolumn{2}{|c|}{ Undialysed } & \multicolumn{2}{|c|}{ Dialysed } \\
\hline & & & $p \mathrm{H} 9 \cdot 0$ & $p \mathrm{H} 6 \cdot 5$ & pH 9.0 & $p \mathrm{H} 6 \cdot 5$ & $p \mathrm{H} \mathrm{9.0}$ & $p \mathrm{H} 6 \cdot 5$ & $p \mathbf{H ~ 9 . 0}$ & $p \mathrm{H} 6 \cdot 5$ \\
\hline \multirow[t]{2}{*}{ Skin } & & $\begin{array}{l}18 \\
19 \\
11 \\
22\end{array}$ & $\begin{array}{l}1 \cdot 23 \\
0 \cdot 23 \\
1 \cdot 07 \\
2 \cdot 10\end{array}$ & $\begin{array}{l}1 \cdot 50 \\
0 \cdot 30 \\
1 \cdot 67 \\
2 \cdot 00\end{array}$ & $\begin{array}{l}0 \\
0 \\
0 \\
0\end{array}$ & $\begin{array}{l}0 \\
0 \\
0 \\
0\end{array}$ & $\begin{array}{l}2.15 \\
0.82 \\
1.93 \\
0.63\end{array}$ & $\begin{array}{l}1.88 \\
0.45 \\
1.33 \\
0.67\end{array}$ & $\begin{array}{l}0 \cdot 23 \\
0 \\
0 \cdot 23 \\
0 \cdot 15\end{array}$ & $\begin{array}{l}0 \cdot 11 \\
0 \cdot 15 \\
0 \cdot 30 \\
0 \cdot 34\end{array}$ \\
\hline & & Mean & $1 \cdot 16$ & $1 \cdot 37$ & 0 & 0 & $1 \cdot 38$ & $1 \cdot 08$ & $0 \cdot 15$ & $0 \cdot 23$ \\
\hline \multirow[t]{2}{*}{ Kidney } & . & $\begin{array}{l}18 \\
19 \\
11 \\
22\end{array}$ & $\begin{array}{l}0 \\
0 \\
0 \\
0\end{array}$ & $\begin{array}{l}0 \\
0 \\
0 \\
0\end{array}$ & $\begin{array}{l}0 \\
0 \\
0 \\
0\end{array}$ & $\begin{array}{l}0 \\
0 \\
0 \\
0\end{array}$ & $\begin{array}{l}2 \cdot 00 \\
1 \cdot 67 \\
2 \cdot 14 \\
9 \cdot 38\end{array}$ & $\begin{array}{l}0 \\
0 \\
0 \cdot 23 \\
0\end{array}$ & $\begin{array}{l}0.23 \\
0.45 \\
0.53 \\
6.25\end{array}$ & $\begin{array}{l}0 \\
0.06 \\
0.08 \\
0\end{array}$ \\
\hline & & Mean & 0 & 0 & 0 & 0 & $3 \cdot 80$ & 0.06 & $1 \cdot 87$ & 0.04 \\
\hline
\end{tabular}

Note. Case 22 was a male infant of 37 weeks' gestation, weighing 1,375 g., who died at 14 days from intracranial haemorrhage.

respectively). This relatively high content of histamine made the calculation of the histidine decarboxylase activity unreliable, since there was often only a small increase in the amount of histamine present after incubation with L-histidine. Calculated as usual by the subtraction of preformed histamine from the total, the mean enzyme activity at $p \mathrm{H} \mathrm{9.0}$ for the hyaline membrane cases was $1.49 \mu \mathrm{g} . / \mathrm{g}$. and for the control cases $1.20 \mu \mathrm{g}$./g. At $p \mathrm{H} 6.5$ the mean values were $0.77 \mu \mathrm{g} . / \mathrm{g}$. and $0.87 \mu \mathrm{g}$./g. respectively.

In an attempt to obtain more accurate estimates of enzyme activity, preformed histamine was eliminated from extracts of skin by dialysis in saline. Unfortunately, this process reduced the activity of the enzyme, an effect that was found after dialysis of kidney extracts as well (Table 4). The mean reduction in activity after dialysis was $61 \%$ compared with a reduction of $18 \%$ for the activity in guinea-pig kidney (unpublished work). The reason for this reduction in activity is not clear. There was no alteration in the volume of the sample during dialysis, and the effect was not due to removal of calcium, magnesium, potassium or phosphate, since addition of these after dialysis and before incubation did not prevent the reduction in activity. It is possible that the effect was due to removal of an unidentified element or to instability of the apoenzyme.

The mean values for preformed histamine in bone marrow from six newborn infants were $0.18 \mu \mathrm{g}$./g. at $p \mathrm{H} 9.0$ and $0.33 \mu \mathrm{g} . / \mathrm{g}$. at $p \mathrm{H} \mathrm{6.5}$. The corresponding mean values for histidine decarboxylase were $0.23 \mu \mathrm{g} . / \mathrm{g}$. and $0.05 \mu \mathrm{g}$. $/ \mathrm{g}$. respectively.

\section{Discussion}

Histidine Decarboxylases. Histidine decarboxylase exists in mammalian tissues in two forms (Weissbach, Lovenberg and Udenfriend, 1961). The first is a specific enzyme acting only on L-histidine. It is most active at $p \mathrm{H} 6.5$ and is not potentiated by benzene. This is the enzyme responsible for the production of large quantities of histamine by the liver of the foetal rat: its presence in human tissues has not been established. 
The second histidine decarboxylase appears to be a general 'non-specific' decarboxylase acting on aromatic amino acids such as 5-hydroxy-tryptophan and 3,4-dihydroxyphenylalanine as well as on histidine; it has been termed 'aromatic $\mathrm{L}$-amino acid decarboxylase' by Lovenberg, Weissbach and Udenfriend (1962). The $p \mathrm{H}$ optimum for this enzyme is 8-9 and its activity is potentiated by the addition of benzene.

Some workers have doubted whether an enzyme active at $p \mathrm{H} \mathrm{8-9}$ and potentiated by benzene can have physiological significance (Ganrot, Rosengren and Rosengren, 1961). Schayer (1963) has even suggested that the activity demonstrated is an artefact. It is true that the demonstration of enzyme activity in vitro, whether by isotopic or nonisotopic methods, is no guarantee that it plays a role in physiological processes in vivo. It seems unlikely, however, that the activity so consistently found in human infant kidney, and so consistently absent from other organs such as lung, and from control incubation mixtures, is either an artefact or devoid of physiological meaning. Moreover, although the enzyme activity is maximal at $p \mathrm{H} \mathrm{8-9}$ in vitro, there is still some activity at lower, more physiological, $p \mathrm{H}$ levels. Weissbach et al. (1961) suggest that the non-specific decarboxylase does play a role in histamine formation in vivo, although the specific enzyme may be the more important.

Histidine Decarboxylase in Infant Tissues. The enzyme found in human infant tissues has the characteristics of the non-specific histidine decarboxylase. It is consistently present in small quantities in the kidneys and liver, but only in trace amounts in most other organs (Mitchell, 1962, 1963). In the present series of experiments, histidine decarboxylase was looked for in abdominal skin, stomach and spleen because Lindberg, Lindell and Westling (1963) have shown that in very small human foetuses (up to $300 \mathrm{~g}$. body weight) these organs can decarboxylate histidine. The results reported here indicate that in larger newborn infants histidine decarboxylating activity is low in these tissues. It should be noted that at $p \mathrm{H} 6 \cdot 5$, as well as at $p \mathrm{H} 9 \cdot 0$, there was evidence of some histidine decarboxylating activity in skin, but not in the other organs tested (Table 4). It is not easy to assess the significance of this finding, however, because of the relatively large amounts of preformed histamine in the skin. As Kahlson (1962a) has pointed out, one of the disadvantages of the nonisotopic method for estimating histidine decarboxylase is its low sensitivity in the presence of high tissue histamine.
If there is specific histidine decarboxylase in the skin, it may be contained in the tissue mast cells (Weissbach et al., 1961; Lindell, Rorsman and Westling, 1961). The small quantity apparently present would be consistent with the low mast cell content of human skin compared with that of most other mammals (West, 1959). Bone marrow was examined because it seemed possible that, since histidine decarboxylation has been demonstrated in basophil leucocytes (Lindell et al., 1961), activity might be high in tissues containing these cells. Kahlson and Rosengren (1963) have reported a high rate of histamine formation in the bone marrow of rats: in contrast, the histidine decarboxylase activity found in the human infants' bone marrow was very low.

It is of some interest that during the course of this work, the opportunity arose to examine the tissues of a premature infant with renal agenesis. The histidine decarboxylase activity of the liver and other organs was within normal limits, despite the absence of kidneys. This suggests that the kidney, though containing the highest concentration of the enzyme, is not a critically important source of histidine decarboxylase and that the normal amounts of enzyme in other organs are adequate for requirements. It has been pointed out (Mitchell, 1963) that although the liver contains much less activity per gramme than the kidneys, it contributes more to the total enzyme activity in the body because of its greater size.

The low values for histidine decarboxylase activity in the tissues of infants dying of hyaline membrane disease, and the fact that they did not differ from the values found in infants dying from other causes, do not support the hypothesis that there is increased histamine production in respiratory distress. On this evidence, it seems unlikely that the beneficial effects of chlorpheniramine are due to specific antagonism of histamine, but rather that they are the result of some other action of the drug. However, possible alterations in the rate of destruction of histamine have not been considered here.

Histamine and Foetal Growth. Most of the experimental work linking histamine with foetal growth has been carried out in rats (Kahlson, $1962 \mathrm{~b}$ ), and very little is known about histamine metabolism in the human foetus (Mott, 1961). Lindberg et al. (1963) have demonstrated low rates of histamine formation in vitro in the tissues of human foetuses obtained at induced abortion. Using an isotopic method, they found relatively higher activity in spleen, skin and stomach than in 
kidney-the reverse of the results reported here for infants born at a later stage of pregnancy. These differences cannot easily be explained except by assuming that the methods measure different decarboxylating activities, and the reservations already made about in vitro methods apply to both studies. It should be noted that the activity found in human foetuses by the Swedish workers was present in early pregnancy, whereas the great increase in histamine production by the rat foetuses occurs later in pregnancy. The low histidine decarboxylating activity reported here in human infants born prematurely in the latter part of pregnancy suggests that the human foetus is unlike the rat foetus in its production of histamine.

The only direct evidence that histamine is abnormally increased in the human foetus is the unpublished work of Kahlson indicating that the level of histamine in foetal arterial blood plasma is high (Kahlson et al., 1959). The data of Bjurö, Lindberg and Westling (1961) are not decisive, for in only four of nine mature infants studied was the histamine content of umbilical arterial blood raised (over $0.1 \mu \mathrm{g} . / \mathrm{ml}$.). Moreover, values for histamine in whole blood cannot be interpreted in the absence of information on the numbers of basophil and eosinophil leucocytes (Mitchell and Cass, 1959).

There are other indications, however, that histamine may be of importance in human reproduction. There is evidence that histamine is necessary for normal nidation of the fertilized ovum (Shelesnyak, 1957). It has been known for some years that plasma levels of histaminase (diamine oxidase) are greatly increased in pregnant women (KapellerAdler, 1956). Recently, Bjurö et al. (1961) reported increased urinary excretion of histamine in pregnancy, though the increase was not consistently present and previous workers have not found this change (Rockenschaub, 1953; Schayer, 1959). Histamine may also be important in the newborn infant, for Snyderman, Boyer, Roitman, Holt and Prose (1963) have shown that histidine is an essential amino acid in early infancy and have suggested that histamine may therefore be necessary as well.

These reports, though by no means conclusive evidence, do indicate the need for further research in this field. The great contribution made by Kahlson and his colleagues has been their demonstration of the importance of studying the dynamic metabolism rather than the static tissue content of histamine. Further advances will depend on finding ways of obtaining information about the metabolism of histamine in the living human foetus and newborn infant.

\section{Summary}

Histidine decarboxylase activity was found in the kidneys of newborn infants dying in the first week of life. Smaller amounts were found in liver, lung, stomach, spleen, bone marrow and skin. The enzyme had the characteristics of non-specific histidine decarboxylase, being active at $p \mathrm{H}$ 8-9 and potentiated by benzene.

There was no significant difference in enzyme activity between infants dying of hyaline membrane disease and infants dying from other causes. This does not support the hypothesis that the beneficial effects of antihistamine drugs in respiratory distress are due to specific antagonism of histamine present in excess.

There was evidence of slight histidine decarboxylating activity at $p \mathrm{H} 6.5$ in skin, but not in other tissues. However, the presence of relatively large amounts of preformed histamine made its significance difficult to assess. Removal of the preformed histamine by dialysis did not help to identify the enzyme more accurately, because dialysis reduced the decarboxylating activity present.

This work was carried out with the aid of a grant from the Asthma Research Council. I am grateful to Dr. Kenneth Rhaney for his co-operation in obtaining infant tissues, and to Professor J. L. Henderson for his help and criticism.

\section{REFERENCFS}

Barsoum, G. S. and Gaddum, J. H. (1935). The pharmacological estimation of adenosine and histamine in blood. J. Physiol. (Lond.), 85, 1.

Bjurö, T., Lindberg, S. and Westling, H. (1961). Observations on histamine in pregnancy and the puerperium. Acta obstet. gynec. scand., 40, 152.

Burkhalter, A. (1962). The formation of histamine by fetal rat liver. Biochem. Pharmacol., 11, 315.

Cook, C. D. (1962). Some aspects of respiratory problems in the newborn. J. Pediat., 61, 105.

Davis, J. A. (1961). Antihistamine drugs in neonatal respiratorydistress syndrome. Lancet, 2, 1451.

Ganrot, P. O., Rosengren, A. M. and Rosengren, E. (1961). On the presence of different histidine decarboxylating enzymes in mammalian tissues. Experientia (Basel), 17, 263.

Kahlson, G. (1960). A place for histamine in normal physiology. Lancet, $1,67$.

(1962a). Nascent histamine and methods of its estimation. In Symposium on Histamine Metabolism. In Proc. XXII Int. Congr. physiol. Sci., Leiden, 1962. Vol. 1. Lectures and Symposia. Part II, p. 856.

(1962b). New approaches to the physiology of histamine. Perspect. Biol. Med., 5, 179.

and Rosengren, E. (1959). Prevention of foetal development by enzyme inhibition. Nature (Lond.), 184, 1238.

(1963). Histamine formation in bone marrow. Experientia (Basel), 19, 182.

, - and White, T. (1959). Formation of histamine by the foetus in the rat and man. $J$. Physiol. (Lond.), 145, 30P.

Kapeller-Adler, R. (1956). The effect of sex hormones on histaminase. In Ciba Foundation Symposium on Histamine, p. 272. Churchill, London.

Lindberg, S., Lindell, S. E. and Westling, H. (1963). Formation and inactivation of histamine by human foetal tissues in vitro. Acta obstet. gynec. scand., 42, Suppl. 1, p. 49.

Lindell, S. E., Rorsman, H. and Westling, H. (1961). Histamine formation in human blood. Acta allerg. (Kbh.), 16, 216.

Lovenberg, W. Weissbach, H. and Udenfriend, S. (1962). Aromatic L-amino acid decarboxylase. J. biol. Chem., 237, 89 .

Mackay, D. and Shepherd, D. M. (1960). A study of potential histidine decarboxylase inhibitors. Brit. J. Pharmacol., 15, 552. 
Mitchell, R. G. (1962). Histidine decarboxylase activity in the human infant. J. Physiol. (Lond.), 164, 20P.

- (1963). Histidine decarboxylase in the new-born human infant. ibid., 166, 136.

and Cass, R. (1959). Histamine and 5-hydroxytryptamine in the blood of infants and children. J. clin. Invest., 38, 595 .

Mott, J. C. (1961). The stability of the cardiovascular system. In Ciba Foundation Symposium on Somatic Stability in the Newly Born, p. 192. Churchill, London.

Rockenschaub, A. (1953). The urinary excretion of histamine in pregnancy and in pre-eclampsia. J. Obstet. Gynaec. Brit. Emp., 60, 398.

Schayer, R. W. (1959). Catabolism of physiological quantities of histamine in vivo. Physiol. Rev., 39, 116.

(1962). Evidence that induced histamine is an intrinsic regulator of the microcirculatory system. Amer. J. Physiol., 202, 66.
(1963). Histidine decarboxylase in mast cells. Ann. N.Y Acad. Sci., 103, Art. 1, p. 164 .

Shelesnyak, M. C. (1957). Some experimental studies on the mechanism of ova-implantation in the rat. Recent Progr. Hormone Res., 13, 269.

Snyderman, S. E. Boyer. A., Roitman, E., Holt, L. E. and Prose P. H. (1963). The histidine requirement of the infant. Pediatrics, 31, 786.

Telford, J. M. and West, G. B. (1961). The effect of age on the formation of histamine in the rat. J. Physiol. (I.ond.), 157, 306. Wade-Evans, T. (1962). The formation of pulmonary hyaline membranes in the newborn baby. Arch. Dis. Childh., 37, 470.

Weissbach, H., Lovenberg, W. and Udenfriend, S. (1961). Characteristics of mammalian histidine decarboxylating enzymes. teristics of mammalian histidine decart.

West, G. B. (1959). Tissue mast cells and tissue amines. J. Pharm. Pharmacol., 11, 513. 